\title{
Are Regional Development Policies Needed?
}

\author{
NiLES HANSEN
}

\begin{abstract}
This paper critically examines the rationales for regional policies in the light of recent changes in the geographic distribution of population and economic activity. Under present circumstances, national policies intended to determine where people should live or where economic activities should be located seem highly questionable. Nevertheless, a Regional Development Agency at the national level could serve a useful function in a learning process involving the entire federal system.
\end{abstract}

\section{INTRODUCTION}

Recent shifts in population and economic activity from the Northeast and North Central parts of the United States to the South and West, and from large metropolitan areas to smaller towns and rural areas have revived interest in the formulation of federal regional policies to deal with problems associated with these changes.

The present paper critically examines the rationale for territorial distribution policies and suggests that it probably is premature to set specific goals at the national level. Nevertheless, it would be valuable to have a Regional Development Agency at the federal level to coordinate a learning process involving the entire federal system.

\section{POSTWAR POLICIES}

Federal policy for promoting economic development in large lagging regions is based primarily on two legislative acts passed in 1965: the Appalachian Regional Development Act and the Public Works and Economic Development Act. During the late 1960s it appeared that the "new regionalism" embodied in the Economic Development Administration, the Appalachian Regional Commission, and similar commissions for five other multistate development regions would at last result in a major comprehensive approach to the difficulties of large regions experiencing high unemployment and low per capita income (Hansen, 1974). Unfortunately this promise was never fulfilled. Although the relevant agencies still exist, they have received relatively little funding in recent years. 
Despite some constructive innovations-especially by the Appalachian Regional Commission with respect to human resource development programs - the regional planning efforts tended to be equated with "antipoverty" programs, and as such they were severely curtailed by the Nixon administration.

Since the Second World War the role of the federal government has become critical in dealing with problems of metropolitan areas. Probably the most pressing intraurban problem in the United States is that of minority ghettos. However, even if the complex issues of racial discrimination and slum poverty were to be solved, there still would be a number of major problems facing the large cities. Economic obsolescence and decay in downtown areas is widespread; though related to the problem of central city ghettos, this phenomenon would probably have arisen in any case because of the rapid suburbanization of metropolitan population and economic activity. Traffic congestion is yet another challenge to the cities, and contributes to the general pollution of the metropolitan environment. The failure of metropolitan areas to respond adequately to these problems is related to the fragmentation of government and fiscal responsibility into rival independent jurisdictions. In 1962, for example, the average Standard Metropolitan Statistical Area (SMSA) contained eighty-seven local government units (seventy-six of which could levy property taxes), comprising 1.5 counties, twenty municipalities, twelve townships, twenty-eight school districts, and twenty-six special districts (Hoover, 1971, p. 374). Even though the federal government has the fiscal capacity to make grants for housing, welfare, education, transportation, and community facilities, as yet no clear and consistent goals and strategies have been formulated to guide metropolitan development policies.

\section{NATIONAL URBAN GROWTH POLICY}

Despite White House reluctance to formulate policies concerning the spatial allocation of population and economic activity, the Congress, in the Housing and Urban Development Act of 1970, declared that a national urban growth should be developed. The act provided for submission by the President to Congress of a biennial report on urban growth. The report should assist in the creation of a national urban growth policy and provide information and data relevant to urban growth. It should also contain a discussion of urban problems and efforts being made at all levels of government to deal with them, as well as recommendations for programs related to national urban growth policy.

The first (1972) growth report was a watered-down compendium of data that implicitly denied the desirability of such a policy. The document reflected the administration's lack of enthusiasm for any active federal role in shaping a national urban policy, and, conversely, its preference for state and local initiatives in this regard. Similarly, the Presi- 
dent's 1974 growth report was lacking in specific recommended policies and programs.

In any event, the 1970 act was a rather poor guide for developing a national strategy. By promising something for everyone-whether in central cities, suburbs, smaller communities, local neighborhoods, or rural areas - and by failing even to hint at priorities, it could be as readily approved as most flag and motherhood bills. It also could be argued that by creating the appearance that a spatial development policy was in the process of being formed, the whole exercise may actually have hindered serious debate about, and the careful articulation of, an operationally feasible growth strategy. Be that as it may, the act nevertheless reflected a widespread mis-perception of the basic spatial economic and demographic changes taking place in the United States.

The data in Table 1 show that in both the 1950s and the 1960s the population growth rate in metropolitan areas substantially exceeded that in nonmetropolitan areas. During the $1950 \mathrm{~s}$, metropolitan areas gained about 25 million residents whereas the nonmetropolitan gain was only 3 million inhabitants; the corresponding values for the 1960s were approximately 20 million and 4 million. By the end of the 1960s there was serious concern in many quarters that something be done by the federal government to promote "more balanced" geographic growth patterns. Otherwise, it was argued, the nation would be plagued by rural decline in much of the country as well as a host of metropolitan problems aggravated by the influx of migrants from nonmetropolitan areas (President's National Advisory Commission, 1967; U.S. Department of Agriculture, 1968; National Goals Research Staff, 1970; Commission on Population Growth, 1971). Thus, a study of 1971 legislative and executive actions concluded that "perhaps the most active component of national urban growth policy in 1971 was concern for the development of smaller urban centers as an option to present metropolitan growth trends (Beckman, 1972 , p. 232)." Implicit here is the notion that big cities are too big and growing even larger while rural areas languish. The same policy orientation still appeared as late as 1975 in a major review of national urban growth policy (Beckman, 1975). But, as often happens to the generals, strategies that were devised in light of the last war have been rendered obsolete by current realities.

\section{DECENTRALIZATION OF POPULATION AND ECONOMIC ACTIVITY}

Recent data from the Current Population Survey of the U.S. Bureau of the Census reveal consistent tendencies in the evolution of population by metropolitan and nonmetropolitan residence (see Table 1). Over the past twenty-five years the growth rate of total national population has declined. However, the growth rate of metropolitan areas has declined even more rapidly. In the 1970-75 period, the metropolitan annual average growth rate ( 0.7 per cent) was actually below that of the nation 
TABLE 1. Population of the United States, by Metropolitan-Nonmetropolitan Residence, 1950-1975 (in thousands, except per cent).

\begin{tabular}{|c|c|c|c|c|c|c|c|c|}
\hline & \multirow[b]{2}{*}{1950} & \multirow[b]{2}{*}{1960} & \multirow[b]{2}{*}{$1970 \mathrm{~A}$} & \multirow[b]{2}{*}{ 1970B2 } & \multirow[b]{2}{*}{1975} & \multicolumn{3}{|c|}{$\begin{array}{l}\text { Average Annual Per } \\
\text { Cent Change }\end{array}$} \\
\hline & & & & & & $\begin{array}{c}1950 \\
\text { to } \\
1960\end{array}$ & $\begin{array}{c}1960 \\
\text { to } \\
1970\end{array}$ & $\begin{array}{c}1970 \\
\text { to } \\
1975\end{array}$ \\
\hline TOTAL & 151,326 & 179,323 & 203,212 & 199,819 & 208,683 & 1.7 & 1.3 & 0.9 \\
\hline Metropolitan Areas ${ }^{1}$ & 94,579 & 119,595 & 139,419 & 137,058 & 141,993 & 2.3 & 1.5 & 0.7 \\
\hline In Central Cities & 53,696 & 59,947 & 63,797 & 62,876 & 60,902 & 1.1 & 0.6 & -0.6 \\
\hline Outside Central Cities & 40,883 & 59,648 & 75,622 & 74,182 & 81,091 & 3.8 & 2.4 & 1.8 \\
\hline Nonmetropolitan Areas & 56,747 & 59,728 & 63,793 & 62,761 & 66,690 & 0.5 & 0.7 & 1.2 \\
\hline
\end{tabular}

${ }^{1}$ All Data refer to the areas of the 243 Standard Metropolitan Statistical Areas defined in 1970 census publications.

${ }^{2}$ For comparability with data from the Current Population Survey, figures from the 1970 census have been adjusted to exclude inmates of institutions and members of the Armed Forces living in barracks and similar types of quarters.

Sources: U.S. Bureau of the Census, Statistical Abstract of the United States: 1972, U.S. Government Printing Office, Washington, D.C., 1972, p. 16. U.S. Bureau of the Census, Current Population Reports, Series P-20, No. 292 "Population Profile of the United States, 1975," U.S. Government Printing Office, Washington, D.C., 1976, p. 23. 
(0.9 per cent) and well below that of nonmetropolitan areas (1.2 per cent). This unprecedented reversal was not simply the latest manifestation of urban sprawl around metropolitan areas as defined in 1970.

By the end of 1975, the Office of Management and Budget had added twenty-nine Standard Metropolitan Statistical Areas (SMSAs) to the number existing in 1970, and many counties were added to the SMSAs as defined in 1970. In addition, thirteen Standard Consolidated Statistical Areas (SCSAs) were newly defined in 1975. These are large agglomerations made up of adjacent SMSAs having a certain level of inter-commuting and generally sharing a continuous urban mass. They are designated only if one of the adjacent SMSAs has a population of at least one million. SCSAs had previously been defined only for New York and Chicago.

An analysis of population changes in this new context indicated that the largest SMSAs in 1970-those with over two million inhabitantsexperienced no growth as a group between 1970 and 1974. Comparisons for the SCSAs which include those SMSAs show essentially the same pattern. Eight of the fifteen largest SMSAs are estimated to be losing population, including the five largest (New York, Los Angeles, Chicago, Philadelphia and Detroit), and only the Dallas-Ft. Worth area now exceeds the national rate of growth. Over 1.7 million more persons moved out of the fifteen largest SMSAs than moved in during the early 1970s; the New York SMSA alone accounted for a net migration loss of half a million persons. During the 1960s these same areas gained a net of 1.1 million migrants but in the 1970-74 period only three gained population through migration, with the greatest gain being barely one per cent. Since 1970 the population of SMSAs with fewer than two million inhabitants has been increasing at about the same rate as nonmetropolitan America, yet this is well below their rate of increase during the 1960s (U.S. Bureau of the Census, 1976).

The data in Table 2 provide further evidence that decentralization tendencies are not simply a matter of extensions just beyond metropolitan areas. Referring to these data, a leading demographer points out that the most dramatic net migration changes have taken place "in those counties with the least commuting to metropolitan areas and in those classified rural nonadjacent. That component of change, in those two categories of counties, carried the clearest message: the more remote kinds of places - those that as a group used to be regarded as 'nowhere'have today become 'somewhere' in the minds of many migrants (Morrison, 1975, p. 12)."

Regional employment change data lend further support to this position. The locus of fastest employment growth shifted from suburban counties prior to the 1969 national economic downturn to nonmetropolitan counties throughout the 1969-72 business cycle. Moreover, nonmetropolitan growth rates were highest in less-developed regions, indicating that employment decentralization was more than mere metropolitan spillover (Nelson and Patrick, 1975). 
Similar findings were obtained from an analysis of employment change between December 31, 1969 and December 31, 1972 for metropolitan and rural areas, by industry group. The geographic units of analysis were the SMSA and non-SMSA (here defined to be rural) components of Bureau of Economic Analysis regions, which basically are labor market areas defined on the basis of commuting patterns. On the basis of Dun and Bradstreet data files, the study found that firms rarely move from one region to another; this runs contrary to the prevalent notion that firms move from one area to another to lower costs. Firms themselves stay where they are presently located or else go out of business. It is entrepreneurs who move and start up new firms in more favorable locations, though the latter may also receive new branch plants of large companies. Moreover, the data presented in Table 3 indicate that entrepreneurs have been rethinking their historical location patterns at least as much as other people have, and maybe more so. Rural areas were growing much more rapidly than metropolitan areas in the early 1970s.

An important consideration in this employment shift is its character. Is it simply a few large manufacturers locating remotely to find cheaper land for single storey plants, or is it complete societies mov--

TABLE 2. Population Change for Groups of Metropolitan and Nonmetropolitan Counties, 1960-1970 and 1970-1973

\begin{tabular}{|c|c|c|c|}
\hline \multirow[b]{2}{*}{ Population Category } & \multirow{2}{*}{$\begin{array}{l}\text { Provisional } \\
1973 \\
\text { Population } \\
\text { (000's) }\end{array}$} & \multicolumn{2}{|c|}{$\begin{array}{l}\text { Annual Population } \\
\text { Growth Rate }\end{array}$} \\
\hline & & 1970-1973 & $1960-1970$ \\
\hline United States & 209,851 & 1.0 & 1.3 \\
\hline Inside $\mathrm{SMSAs}^{1}$ (Metropolitan) & 153,350 & 0.9 & 1.6 \\
\hline $\begin{array}{l}\text { Outside SMSAs (Nonmetropolitan) } \\
\text { In Counties from which: }\end{array}$ & 56,500 & 1.3 & 0.4 \\
\hline$\geq 20 \%$ commute to SMSAs & 4,099 & 1.9 & 1.0 \\
\hline $10 \%-19 \%$ commute to SMSAs & 9,683 & 1.4 & 0.7 \\
\hline$<10 \%$ commute to SMSAs & 42,719 & 1.2 & 0.3 \\
\hline $\begin{array}{l}\text { Entirely rural counties } \\
\text { not adjacent to an } S M S A^{2}\end{array}$ & 4,401 & 0.9 & -0.4 \\
\hline
\end{tabular}

Source: P. A. Morrison, The Current Demographic Context of National Growth and Development. Santa Monica, Calif., Rand Corporation, September 1975, p. 10. Data are from Richard L. Forstall, "Trends in Metropoliłan and Nonmetropolitan Population Growth Since 1970," forthcoming; and Calvin L. Beale, The Revival of Population Growth in Nonmetropolitan America, ERS-605 Economic Development Division, Economic Research Service, U.S. Department of Agriculture, June 1975.

${ }^{1}$ SMSAs defined as of December 31, 1974, except in New England, where definitions in terms of entire counties have been substituted.

2"Entirely rural" means the counties contain no town of 2500 or more inhabitants. 
TABLE 3. Average Components of Employment Change for Metropolitan and Rural Areas by Industry, 1970-1972

\begin{tabular}{|c|c|c|c|c|c|c|c|}
\hline \multicolumn{8}{|c|}{ AGRICULTURE } \\
\hline & $\begin{array}{c}\text { NET } \\
\text { CHANGE }\end{array}$ & BIRTHS & DEATHS & EXPANSION & CONTRACTION & $\begin{array}{c}\text { IN- } \\
\text { MIGRATION }\end{array}$ & $\begin{array}{c}\text { OUT- } \\
\text { MIGRATION }\end{array}$ \\
\hline METRO & $-3.6 \%$ & $3.8 \%$ & $-7.7 \%$ & $15.9 \%$ & $-16.5 \%$ & $1.1 \%$ & $-0.3 \%$ \\
\hline RURAL & $-1.7 \%$ & $5.0 \%$ & $-10.4 \%$ & $18.1 \%$ & $-14.3 \%$ & $0.1 \%$ & $-0.1 \%$ \\
\hline \multicolumn{8}{|c|}{ MANUFACTURING } \\
\hline & $\begin{array}{l}\text { NET } \\
\text { CHANGE }\end{array}$ & BIRTHS & DEATHS & EXPANSION & CONTRACTION & $\begin{array}{l}\text { IN- } \\
\text { MIGRATION }\end{array}$ & MIGRATION \\
\hline METRO & $-10.0 \%$ & $3.0 \%$ & $-11.8 \%$ & $9.1 \%$ & $-10.2 \%$ & $0.2 \%$ & $-0.2 \%$ \\
\hline RURAL & $-5.5 \%$ & $3.5 \%$ & $-12.3 \%$ & $11.3 \%$ & $-8.1 \%$ & $0.4 \%$ & $-0.2 \%$ \\
\hline \multicolumn{8}{|c|}{ OTHER INDUSTRY } \\
\hline & CHANGE & BIRTHS & DEATHS & EXPANSION & CONTRACTION & MIGRATION & MIGRATION \\
\hline METRO & $-2.7 \%$ & $6.3 \%$ & $-11.3 \%$ & $15.0 \%$ & $-12.7 \%$ & $0.2 \%$ & $-0.2 \%$ \\
\hline \multirow[t]{3}{*}{ RURAL } & $0.2 \%$ & $6.9 \%$ & $-13.7 \%$ & $18.3 \%$ & $-11.4 \%$ & $0.5 \%$ & $-0.4 \%$ \\
\hline & \multicolumn{7}{|c|}{ TRADE } \\
\hline & CHANGE & BIRTHS & DEATHS & EXPANSION & CONTRACTION & MIGRATION & MIGRATION \\
\hline METRO & $2.7 \%$ & $10.9 \%$ & $-15.3 \%$ & $15.1 \%$ & $-7.9 \%$ & $0.2 \%$ & $-0.2 \%$ \\
\hline \multirow[t]{3}{*}{ RURAL } & $14.0 \%$ & $14.3 \%$ & $-16.7 \%$ & $22.8 \%$ & $-6.4 \%$ & $0.2 \%$ & $-0.2 \%$ \\
\hline & \multicolumn{7}{|c|}{ SERVICE } \\
\hline & CHANGE & BIRTHS & DEATHS & EXPANSION & CONTRACTION & MIGRATION & MIGRATION \\
\hline METRO & $1.6 \%$ & $4.7 \%$ & $-7.1 \%$ & $12.6 \%$ & $-8.7 \%$ & $0.3 \%$ & $-0.3 \%$ \\
\hline \multirow[t]{3}{*}{ RURAL } & $8.3 \%$ & $9.2 \%$ & $-11.2 \%$ & $20.9 \%$ & $-10.7 \%$ & $0.2 \%$ & $-0.1 \%$ \\
\hline & NET & & TOTAL & & & IN- & OUT- \\
\hline & CHANGE & BIRTHS & DEATHS & EXPANSION & CONTRACTION & MIGRATION & MIGRATION \\
\hline METRO & $-3.9 \%$ & $5.6 \%$ & $-11.7 \%$ & $12.0 \%$ & $-9.8 \%$ & $0.2 \%$ & $-0.2 \%$ \\
\hline RURAL & $1.5 \%$ & $7.3 \%$ & $-13.6 \%$ & $16.1 \%$ & $-8.4 \%$ & $0.3 \%$ & $-0.2 \%$ \\
\hline
\end{tabular}

Source: P. M. Allaman and D. L. Birch (1975), Components of Employment Change for Metropolitan and Rural Areas in the United States by Industry Group, 1970-72, Inter-Area Migration Project Working Paper No. 8, Joint Center for Urban Studies of M.I.T. and Harvard University, Cambridge, Mass. 
ing out, with stores and offices and automobile dealers and bowling alleys and all the other forms of enterprise that make up an-integrated economy? In partial resolution of this question, we broke the components of change into metropolitan and rural parts for each of our five industry types. The result is quite clear. All forms of activity are moving out-particularly trade and service. It would appear that, as a nation, we are finding ways to live and work in the countryside, and have been capitalizing on that possibility far more in the past few years than in the previous few decades (Allaman and Birch, 1975, p. 14).

Thus, it is clear that changes in the metropolitan-nonmetropolitan settlement pattern of the United States have spontaneously taken the direction advocated by most proponents of a national policy to promote more "balanced growth" in favor of nonmetropolitan areas. Ironically, calls for the creation of a President's Council of Regional Advisers (comparable to the present Council of Economic Advisers) and for effective regional economic policies may be realized because of metropolitan. decline rather than metropolitan growth. The matter is one of the politics of numbers. About 73 per cent of the nation's population still lives in SMSAs and the combined populations of the fifteen largest SMSAs (58.8 million in 1974) still is greater than the nonmetropolitan total (56.4 million).

\section{REGIONAL POLICY: WHAT ARE THE ISSUES?}

\section{Metropolitan Growth}

Despite the decline or stagnation of many of the largest SMSAschiefly in the Northeast and North Central regions-many smaller SMSAs-mainly in the South and West-continue to grow at very rapid rates. For example, between April 1, 1970 and July 1, 1974, metropolitan Florida grew by 19 per cent, Arizona by 21 per cent, and the Mountain States as a whole by 15 per cent. Thirteen SMSAs had growth rates exceeding 20 per cent during this period. Seven of these are located in Florida and two each in Colorado, Arizona and Texas.

Employment and population growth well in excess of the national rate implies rapid inmigration, which in turn may lead to deterioration of overburdened public facilities, congestion, housing shortages, and local price inflation. To be sure, many local tradesmen and owners of real estate will benefit from growth and price inflation, but at the expense of transfer payments from others in the local economy. For example, increased rents and land prices do not create new wealth or income; they rather reflect the increased scarcity of housing and land in simple supply and demand terms, and those who own the relatively scarce resources gain at the expense of those who do not.

In presenting the case for rapid local growth, real estate developers frequently attempt to demonstrate that their projects will increase the tax base, create more trade for local business, stimulate new employment 
opportunities, and generally improve the economy of the community. What they neglect to discuss are the full social costs of these projects. What will rapid growth do to the community's school system, public services, public utilities, transportation, and recreation facilities? What will it cost to meet the new demands resulting from growth? Most city and county officials have been too busy sorting out their day-to-day problems to have time to come to grips adequately with such questions. Nevertheless, they tend to be less willing than formerly to assume that new growth automatically brings new jobs and more tax benefits, reflecting the personal experience of many taxpayers that the full costs required to accommodate growth can be more than the corresponding benefits. Indeed, a large and growing number of places now have, or are seriously considering, legal constraints on future growth.

\section{Nonmetropolitan Growth}

Many factors have contributed to the decentralization of population and economic activity in recent years. Nonmetropolitan areas with attractive natural amenities (good climate, forests, lakes, mountains) have developed rapidly on the basis of tourism, recreation, second homes and retirement homes. Numerous previously-marginal agricultural and mining areas have experienced vigorous expansion because of world-wide scarcities in the primary sector. Manufacturing activities have been decentralizing for some time to regions with abundant supplies of relatively cheap labor-though areas with large minority populations, e.g. blacks, Indians, and Mexican-Americans-have tended to be by-passed by this phenomenon. Tertiary activities have decentralized in response to the movement of the people who represent their market. Moreover, improved transportation (notably the Interstate Highway System) and communications systems have permitted movement to more remote places without significant loss of access to business and household opportunities elsewhere. Indeed, the broader spatial framework in which people live and work makes it ever more difficult to distinguish between what is properly "rural" and what is properly "urban".

While on the surface the attractive blending of rural and urban lifestyles represents one of nonmetropolitan America's major successes, in many places growth is no longer regarded as an unmixed blessing. There has been substantial rethinking about the ecologically damaging aspects of tourism, recreation, and second-home expansion, and even industrial development is no longer a sacred cow. Yet economic development may be needed if employment opportunities are to be extended to low-income persons. In some regions, e.g. the Upper Great Lakes, northern New England, and the Rocky Mountains, a key issue appears to be how to bring about desirable development for the many rather than preservation of a natural endowment for the benefit of an elite few. However, with proper planning development need not necessarily be accompanied by air and water pollution or the devastation of natural beauty. Some areas 
may serve one use today and still be preserved for other uses later. For example, proper mining and timber production may be compatible with and even enhance recreation opportunities in the future. Thus development need not be discouraged, provided that industry adequately controls its wastes, satisfactorily relates to existing land uses and esthetic qualities, and accounts to the community for the full social costs of its activities.

\section{Nonmetropolitan Decline}

It may be argued that attempts to stem the migration of workers from areas with little employment opportunity can be a serious drag on needed adaptation. On the other hand, the selective nature of outmigration means that these areas tend to lose their most vital people--the best workers, the young, the better educated. Moreover, in addition to the initial reduction in employment (or, if the migrants were unemployed, the reduction in transfer payments of a welfare nature) there may be adverse multiplier effects. If outmigration leads to absolute population decline the tax base will be decreased, leading in turn to higher average tax levels or to a deterioration in public service standards. In either case the area's attractiveness to industry is likely to be reduced. Marginal firms may leave the area, creating further adverse multiplier effects. The value of real estate may decline with depopulation, causing banks and other financial institutions to be more strict in granting credit. Depopulation and declining purchasing power may also cause some marketoriented producers to curtail production and cause still more unemployment. Furthermore, when new job opportunities appear in a lagging area there often is a return movement of workers who frequently are more skilled than the members of the local work force; the hard-core unemployed may, under such conditions, find little relief for their problems (Parr, 1966).

Because not all nonmetropolitan areas have significant growth potential, it may be more sensible to organize an orderly retreat than to fan false hopes for future growth. Parts of the Great Plains, for example, have had heavy outmigration for several decades. Although this phenomenon has been viewed with alarm in some quarters, it is difficult to compare the Plains and other relatively prosperous areas with heavy outmigration to the situation in areas such as the Mississippi Delta and south Texas. In the Plains, for example, outmigrants generally have been well prepared to take advantage of economic opportunities elsewhere. Of course, the population left behind has a relatively high proportion of older people and it is often difficult to maintain essential services for a widely dispersed population. However, agriculture is viable and there is relatively little poverty. In addition to savings and farm income there is considerable income from federal government transfer payments. There also are viable small towns, though they probably should be developed as service centers for rural hinterlands rather than as 
growth centers capable of halting and even reversing outmigration. In contrast, outmigrants from poor declining areas frequently are not prepared for job opportunities elsewhere. Moreover, the return migration problem indicates that the basic problem in these areas is underinvestment in their human resources. This suggests that public policy measures in lagging regions should emphasize active manpower and human resource problems. The nation may also deem it desirable to aid, in these areas, persons whose prospects for either local employment or for retraining and migration are not bright; older workers in particular would fall into this category. But it must be recognized that here we are talking about welfare and not about economic development policy.

\section{Metropolitan Decline}

Until recently the United States has had almost no experience with population stagnation or decline in large metropolitan areas. However, because large SMSAs have relatively high per capita incomes it is not likely that they will be faced with the same difficulties confronting declining and economically lagging nonmetropolitan areas. Nevertheless it may be anticipated that they will face new problems as well as new opportunities.

They will have fewer young persons than today and thus fewer children in school. Decisions will have to be made concerning whether to reduce the number of teachers or increase the ratio of teachers to pupils, and whether to close some schools for economy or use school facilities and faculties for new community purposes. Because of their relative scarcity, young people may benefit from greater social and economic mobility. But there also is a possibility that the preponderance of old people and limited expansion will serve to close opportunities to young people. Possibly economic evolution will create more shocks because changes in the local economy and occupational structure will take place more by substitutions and less by new additions. In any case the construction sector and activities linked to it are likely to retrench. Minorities may be frustrated by a lack of new activities into which they can move and by the pre-emption of old activities. On the other hand, they may benefit from the lessening of competition for the older housing stock, which would allow the average family more space as well as lower rents. Decline or stagnation will also require fiscal adjustments at the local level. Whether and to what extent a disjunction takes place between revenues and service costs will depend in large measure on the nature of socio-economic changes, for it must be emphasized that there will continue to be large exchanges of people among cities. If the socio-economic composition does not alter adversely it should be possible to adapt so that prosperity is maintained (Alonso, 1973; Morrison, 1975).

\section{Central City-Suburban Disparities}

Countless books and articles have been written about the separation of the poor, the old, and racial minorities in central cities from better 
housing, and more, better and faster-growing employment opportunities in metropolitan suburbs. Urban renewal and attempts to refurbish the ghettos have not been adequate responses to this problem. Unless a greater effort is made to give ghetto residents a chance to live in suburban locations they will not have access to the full range of opportunities in the metropolis-and it is this access which is the heart of what cities are about. If substantial and sustained progress were made in this regard central cities might once again be made attractive to a broader spectrum of people. This, together with the energy crisis and an apparent taste among young adults for later marriage and fewer children could put a brake on, and perhaps even reverse, the centrifugal tendencies discussed earlier in this paper; it also could do much to overcome existing needs and fiscal capacity imbalances between central cities and suburbs. Clearly we are still a long way from organizing effectively to attain more rational suburban development and to bring about solutions for central city-suburban conflicts. Although the issues have been sharpened in recent years and have been given wide publicity, the federal government has shown a marked predilection for having state and local problems dealt with at these levels. Thus, for now the extent to which states and communities can be and will be responsive to the problems raised here represents a fundamental test of American democracy.

\section{PUBLIC PREFERENCES}

The results of attitudinal surveys do not represent votes on specific issues but they do provide insights into public awareness of them. In recent years a number of public opinion surveys have indicated that concern about population distribution is widespread and is felt by respondents from all socio-economic classes, living in a variety of geographic locations (e.g. Mazie and Rawlings, 1972; Fuguitt and Zuiches, 1975; Zuiches and Fuguitt, 1976). The most recent report available at this writing (Zuiches and Fuguitt, 1976) suggests that a majority of respondents favored discouraging urban industrial growth; however, from twothirds up to 90 per cent supported various specific programs for improving the quality of life in nonmetropolitan areas. This survey was based on data obtained in late 1972, at which time many of the largest SMSAs already were declining and there was positive net migration to nonmetropolitan areas. Were survey respondents reacting to the actual situation in late 1972 or were they responding to widespread publicity still given to rapid metropolitan growth and concomitant rural stagnation and decline? Or did (and do) people believe that big cities are too big even though they may not be growing?; and that nonmetropolitan areas need more support even though they may be growing? To complicate matters further, the absolute growth of population in SMSAs between 1970 and 1975 was greater than that in nonmetropolitan areas, even though the growth rate was substantially less (see Table 1 ); whatever the significance of this phenomenon, it undoubtedly was not pondered by the typical survey respondent. 
All that can be said about the relevant survey findings is that people say they believe that spatial distribution issues are important even if their perception of changing distribution patterns is imperfect. But can governments respond to "public preferences" under such conditions? One of the major conclusions to a study of regional policies in nine Western Countries was that "what is needed most from the whole range of persons concerned with regional policies is not hasty selection of general 'goals,' but a better elucidation of what the problems really are (Hansen, 1974)." This also appears to be the case in the present context.

\section{THE FEDERAL BUDGET}

Even though the federal government does not have a consistent, coherent regional development policy, there no doubt are many unplanned consequences of the concentration of federal outlays in particular places. In the South, for example, such projects as the Tennessee Valley Authority, the McClellan-Kerr Waterway (the largest and most expensive project ever undertaken by the U.S. Army Corps of Engineers), Cape Canaveral, the Redstone Arsenal and the Johnson Space Center have had substantial local growth impacts. It also has been argued that by favoring relatively low-income states, federal categorical grant programs have on balance benefited the South, especially since they fail to correct for lower living costs in that region. On the other hand, there is evidence that federal investments in human resources have been relatively low in lagging regions (Hansen, 1971, pp. 71-75; Committee, 1971). Yet another study found that "however unintentional federal spending has most benefited the more remote reaches of the nation;" the same study nevertheless concluded that even though it was initiated on the assumption that the federal budget "had become so large that the federal outlays were of sufficient importance to remake the economic geography" of the United States this assumption "has not been confirmed by the analysis. The low correlations between federal outlays and population growth and per capita income were disappointing. High per capita federal outlays are not necessarily a prerequisite for growth or high income levels, nor is their presence an assurance of their occurrence (Browning, 1973, p. 62)."

\section{UNANSWERED QUESTIONS}

To sum up the argument so far, it would appear that regional development processes, as well as the impact of federal outlays upon them, are very imperfectly understood. Questions of the relationship between city size and economic efficiency also are far from being resolved (Mera, 1973; Sveikauskas, 1975; Gilbert, 1976). Although survey results indicate that concern about human settlement patterns is widespread, almost nothing is known about the priorities people attach to spatial distribution issues in relation to other social and economic problems. Moreover, it may be more advisable to attack many problems directly rather than by trying to alter the sizes of places. For example, action can be taken 
to eliminate air pollution by prohibitions of noxious activities or by taxes; these devices are flexible enough to permit experiments that would be reversible, in contrast to strategies that would change city size. Other problems are largely political and social rather than physical.

Finally, a common theme in proposed spatial development strategies is the notion of "balanced" growth or a "balanced" distribution of employment. However, what this means is rarely specified in more concrete terms. Does it mean that equality of per capita public infrastructure, income, or economic activity (however defined) should be the goal? Should the growth of less-developed regions be promoted solely by moving resources to them or exploiting more fully resources within their boundaries? Precisely what public and private activities should be located in various types of cities and regions? What effects will the location of various types of activities in a given region have on other regions as a result of induced activities (on both the supply and demand sides) of an interregional nature? What conflicts might arise between maximizing regional and national welfare, and how should they be resolved? Until questions such as these are answered, the appeal to balance is not operationally feasible.

Given the difficulties outlined here, it is highly questionable whether policy makers should attempt to determine where people should live or where economic activities should be located.

\section{REGIONAL DEVELOPMENT AS A LEARNING EXPERIENCE}

This is not to say that issues of territorial distribution should simply be ignored by the federal government. Indeed, I believe it would be desirable and feasible to establish a Regional Development Agency at the national level. Such an agency should be attached to the White House and be independent of any Cabinet member, who might give major attention to his own relatively narrow objectives and programs and then try to force-whether consciously or unconsciously-the accommodation of other departments' programs to his own interests. The RDA should not adopt a narrow focus on problems of "distressed" areas nor should it get caught up in broad but operationally meaningless attempts to achieve "balanced" geographic growth. Rather, it would be more reasonable and more effective to permit flexible approaches to a wide variety of regional situations. Stimulation of economic growth may be a feasible policy for some lagging areas with genuine growth potential; other situations may call for measures which ease adaptation to stagnation or decline; and still other situations may call for better control or management of growth.

Initially the RDA may be viewed as an investment in a learning process. Better understanding of development processes is a necessary precondition for formulating specific, effective regional policies. Similarly, much more knowledge is needed concerning the expected consequences of interregional migration and the magnitudes of the externalities associated with migration. As a recent major review of research on migration 
in the United States points out, the extensive literature dealing with the determinants of migration is "almost completely devoid of direct policy implications (Greenwood, 1975, p. 421)."

Another function of the RDA could be that of monitoring government expenditures. Attempts should be made to disaggregate the federal budget along regional as well as program and project lines. The regionalization of the French budget has proven useful both in providing information for analyzing regional needs and in controlling the implementation of regional objectives; careful investigation of the successes and shortcomings which have marked this efiort over the past decade should prove instructive. By examining the territorial dimensions of the vast array of complex and sometimes conflicting federal programs, the RDA could promote a more equitable distribution of federal cutlays. There often are good reasons for concentrating given funds in certain areas, but even so it would be desirable to evaluate whether some areas and institutions are being unduly favored as a result of a self-perpetuating, self-justifying system. The favored position maintained by some states, cities, and institutions may have more to do with their know-how in manipulating federal agencies than with considerations of efficiency or need.

A flexible national territorial distribution policy might best be implemented through a comprehensive system of multistate regional commissions comparable to that created for the Appalachian regional development program. In this sense a regional commission would not, strictly speaking, be a federal agency but a cooperative venture in which the states and the federal government participate as equals. Each commission would be composed of the relevant governors (or their representatives) and a federal co-chairman appointed by the President. Regional, state, and substate multicounty planning areas-which have been delineated now in nearly all states-would each have their own responsibilities. The regional commission, in cooperation with the RDA, would assess regional problems and opportunities and be concerned with formulating regional programs, planning for public infrastructure, encouraging interstate cooperation, and undertaking social and economic analyses. The States would be responsible for developing long run programs and annual project plans geared to each substate planining area. The latter would be responsible for communicating local needs and aspirations to the states, identifying priority local development projects, and coordinating their local execution.

Through the vehicle of regional commissions it would be possible to have state and local officials and leaders prepare programs that would be federally-financed, but to preserve at the same time a federal veto over programs and projects that would be contrary to efficient resource allocation from a national perspective. Of course, some modifications would have to be made with respect to the last stipulation because regional policies often are the product of grievances-real or imagined-whose satisfaction is not amenable to solutions based solely on national eco- 
nomic efficiency arguments. Still it would be undesirable to abandon economic efficiency altogether when confronted with goals of a largely socio-political nature. Gordon Cameron correctly points out that:

although political pressures give regional policy its main justification and its ever-changing vitality, efficiency arguments are never far beneath the surface. There are two possible meanings of efficiency in this context. The first is concerned with questions of how to devise regional policies which maximize the growth in real G.N.P., probably with a long-term perspective in mind. The second is concerned with using public resources and public policies in such a way that the goals of regional policy are achieved efficiently. This might imply a rule of minimum social costs for the achievement of a given "quantum" of regional goals (Cameron, 1974).

Again though we are in a sphere where lack of knowledge makes it difficult to be confident about the precise ends and means of regional programs. In any event, the RDA should not itself try to sit in judgment with respect to the conflicting and sometimes self-serving demands of local areas. This function belongs to established political institutions and processes; any attempt to assume it by the RDA would no doubt result in its rapid demise. However, if the RDA could fulfill the more modest tasks proposed here, it would have made a major contribution to opening new possibilities for dealing more rationally with problems related to the structure and evolution of human settlement systems; and to creating efficiently more equal access to social and economic opportunities for the whole of the national population.

\section{REFERENCES}

Allaman, P. M. and D. L. Birch (1975) Components of Employment Change for Metropolitan and Rural Areas in the United States by Industry Group, 1970-1972, Inter-Area Migration Project Working Paper No. 8, Joint Center for Urban Studies of M.I.T. and Harvard University, Cambridge, Mass.

Alonso, W. (1973), Urban Zero Population Growth, Daedalus, 102, 4, 191-206.

Beckman, N. (1972), Toward Development of a National Urban Growth Policy: A Legislative Review, Journal of the American Institute of Planners, 38, 4, 230-240.

Beckman, N. (1975), National Urban Growth Policy: 1974 Congressional and Executive Action, Journal of the American Institute of Planners, 41, 4, 234-249.

Browning, C. E. (1973), The Geography of Federal Outlays, Studies in Geography No. 4, Department of Geography, University of North Carolina, Chapel Hill.

Cameron, G. (1974), Regional Economic Policy in the United Kingdom, in Hansen (1974), $2-3$.

Commission on Population Growth and the American Future (1971), Population Growth and America's Future, CPGAF, Washington, D.C.
Committee on Government Operations, U.S. Senate, 92nd Cong., 1st sess. (1971), The Distribution of Federal Outlays among U.S. Counties, part 3 of The Economic and Social Condition of Rural America in the 1970's, U.S. Government Printing Office, Washington, D.C.

Fuguitt, G. V. and J. J. Zuiches (1975), Residential Preferences and Population Distribution, Demography, 12, 3, 491-504.

Gilbert, A. (1976), The Arguments for Very Large Cities Reconsidered, Urban Studies, 13, 1, 27-34.

Hansen, N. M. (1971), Intermediate Size Cities as Growth Centers, Praeger, New York.

Hansen, N. M., ed. (1974), Public Policy and Regional Economic Development, Ballinger, Cambridge, Mass.

Hansen, N. M. (1974), Regional Policy in the United States, in Hansen (1974), 271-304.

Hoover, E. M. (1971), An Introduction to Regional Economics, Alfred A. Knopf, New York.

Mazie, S. M. and S. Rawlings (1972), Public Attitudes Toward Population Distribution Issues, in S. M. Mazie, ed., Population, Distribution, and Policy, U.S. Commission on 
Population Growth and the American Future, vol. 5 of Commission Research Reports, U.S. Government Printing Office, Washington, D.C.

Mera, K. (1973), On the Urban Agglomeration and Economic Efficiency, Economic Development and Cultural Change, 21, 2, 309-324.

Morrison, P. A. (1975), The Current Demographic Context of National Growth and Development, P-5514, Rand Paper Series, Rand Corporation, Santa Monica.

National Goals Research Staff (1970), Toward Balanced Growth: Quantity with Quality, NGRS, Washington, D.C.

Nelson, K. P. and C. H. Patrick (1975), Decentralization of Employment during the 1969-1972 Business Cycle: The National and Regional Record, Oak Ridge National Laboratory, Oak Ridge, Tennessee.

Parr, J. B. (1966), Outmigration and the De- pressed Area Problem, Land Economics, 42 2, 149-159.

President's National Advisory Commission on Rural Poverty (1967), The People Left Behind, PNACRP, Washington, D.C.

Sveikauskas, L. A. (1975), The Productivity of Cities, Quarterly Journal of Economics, 89, 3, 393-413.

U.S. Department of Agriculture (1968), Communities of Tomorrow: Agriculture 2000, USDA, Washington, D.C.

U.S. Bureau of the Census (1976), Current Population Reports, Series P-25, No. 618, "Estimates of the Population of Metropolitan Areas, 1973 and 1974, and Components of Change Since 1970," U.S. Government Printing Office, Washington, D.C.

Zuiches, J. J. and G. V. Fuguitt (1976), Public Attitudes on Population Distribution Policies, Growth and Change, 7, 2, 28-33. 